Weed Science 2017 65:203-205

(C) Weed Science Society of America, 2017

\title{
Another view
}

\author{
K. Neil Harker, Carol Mallory-Smith, Bruce D. Maxwell, David A. Mortensen, and
} Richard G. Smith*

\begin{abstract}
Weed resistance to herbicides occurs when herbicides are overused and can be mitigated by reducing their use. Consensus on herbicide resistance management strategies is problematic given strong industrial profit motive links in the weed science discipline.

Key words: Alternative weed management, herbicide resistance, herbicide-use frequency, integrated weed management.
\end{abstract}

It has recently been suggested that herbicide resistance (HR) is a "wicked" problem (Barrett et al. 2016; Shaw 2016), i.e., it is a problem "without clear causes or solutions." To say that HR is a problem without clear causes or solutions is an affront to much that weed scientists know about HR. Almost all weed scientists agree that HR evolves rapidly when the same herbicide mechanism of action is overused. Furthermore, almost all weed scientists agree that one can delay the evolution of a specific HR problem by using a specific herbicide mechanism of action less frequently. Weed science credibility and progress requires admission that herbicides should be used less frequently; integrated herbicide management is not the answer (Harker et al. 2012; Mortensen et al. 2012). The real problem is to find suitable herbicide alternatives so growers can use herbicides less often.

It may be correct to suggest that convincing industry and growers to manage HR for long-term sustainability is a "wicked" problem. Jussaume and Ervin (2016) state that "there is no consensus as to why some growers do not diversify their tactics." It is difficult to convince growers that the simple, relatively cheap, and very effective herbicide approach should be balanced with approaches that are more complicated and that may be more expensive and less effective. Industry representatives and extension personnel, from whom growers receive a large

DOI: $10.1017 /$ wsc. 2016.30

*First author: Research Scientist, Agriculture and Agri-Food Canada, Lacombe Research Centre, 6000 C \& E Trail, Lacombe, Alberta, Canada T4L 1W1; second author: Professor, Oregon State University, Corvallis, OR 97331-3002; third author: Professor, Montana State University, Bozeman, MT 59717; fourth author: Professor, Pennsylvania State University, University Park, PA 16802; fifth author: Associate Professor, University of New Hampshire, Durham, NH 03824. Corresponding author’s E-mail: neil.harker@agr.gc.ca proportion of their information, are likely to suggest that alternatives to herbicides mean returning to hard times. However, Ervin and Jussaume (2014) suggest that a "technology-focused approach" to HR management may not only increase HR but also make it worse by "delaying the development of holistic approaches." Coble and Schroeder (2016) note that it is critical that those suggesting HR management recommendations are "sending the same message and that message is based on sound science." The message cannot be "we do not know how the problem is caused and we do not know how to solve it." The message should be clear-practice true integrated weed management and find ways to scale back herbicide use.

Given the fact that no major new herbicide mechanism of action has been registered for almost $25 \mathrm{yr}$ (Duke 2012), one might assume that the herbicide industry would wish to "carefully steward" existing herbicides. Unfortunately, true stewardship, which would necessitate limiting sales volume, conflicts with the reality of the herbicide industry's business model, which necessitates maximizing profit during patent-protection periods. Herbicide registrations and sales practices in the generic (off-patent) herbicide business also are motivated by profit maximization. While the research and development divisions of herbicide companies may view herbicide sales strategies as being at odds with HR management, it is difficult to imagine an effective and long-lasting sales team whose goal is to restrain sales. Sales divisions hire people who are "good at selling things." Furthermore, should one company decide to practice good stewardship and limit sales volume, it is certain that a competing company would quickly and happily step into the farmer-client and treated-acre sales void. The latter dynamic makes it extremely difficult for companies to cooperate with one another in the interest of

Harker et al.: Another view • 
preserving herbicide efficacy. Accordingly, it is not surprising that a company with a long-term herbicide stewardship plan has yet to come forward. Herbicide sales strategies are made at the marketing level. Weed scientists who think the herbicide industry will want to forgo profits to maintain product durability are ignoring the overwhelming drivers of business motivation.

This is where the Weed Science Society of America (WSSA) should play the role of a science discipline. As the leading scientific society for researchers who study weeds and their management, the WSSA should be providing "science-based information to the public and policy makers," as described in their mission statement (WSSA Mission Statement, emphasis added). The science is clear; the only way to prevent or delay HR over the long term is to minimize the use of herbicides. The science is clear, too, that crops can be produced without heavy reliance on herbicides, but this requires diversification of cropping systems and true integrated weed management (Davis et al. 2012; Harker et al. 2016). Yet, these are not the consistent messages coming from the WSSA or its flagship journals. Why not? The answer is likely due, in large part, to the weed science discipline's historical legacy and close association with the chemical industry. Indeed, the discipline was born largely out of World War II-era advances in chemistry and the nascent chemical industry it spurred (Zimdahl 1991). That the partnership between the science and the industry remains strong today is reflected in the heavy industry representation among the society's membership at large and among its governing board members, as well as the overwhelming representation by industry among sponsors of the society and its annual meetings (e.g., the six presidentiallevel sustaining members of WSSA are: BASF, Bayer CropScience, Dow AgroSciences, DuPont, Monsanto, and Syngenta).

We would argue that real solutions to the HR problem will not occur until the industrial profit motive is removed from the dilemma and the science is not conflicted. On the one hand, the herbicide industry directly influences the practices adopted by growers through the markets they have worked to develop with growers and local co-ops (local distributors). On the other hand, the close publicprivate sector relationship between industry and public sector scientists is another way herbicidebased solutions are reinforced. There is a very real conflict of interest that arises when private sector sources of applied research funds reinforce reliance on herbicidal solutions (Davis et al. 2009). Incentives and regulations need to be explored that are independent of the influence of the herbicide industry. The science is largely in place (Mortensen et al. 2012) to create real regulation and incentive programs, not to mention real on-the-ground nonconflicted solutions (e.g., Walsh et al. 2013).

Ultimately, growers and their consultants are responsible for the decisions that will significantly delay HR evolution. In the field, where HR evolution occurs, farm-level decisions to accept less shortterm profit for longer-term sustainability will have the largest impact on HR management. It will not be an easy transition; herbicides are the easiest and most effective (Maxwell and O'Donovan 2007) form of weed management, and externalities associated with their use go largely unaccounted for. Also, their widespread adoption enabled farms to increase in size (MacDonald et al. 2013), further challenging tractable, ecologically oriented solutions on larger farms. It is clear that appropriate farm-level HR management decisions are not enhanced when weed scientists suggest $\mathrm{HR}$ is a problem without clear causes or solutions. It is also clear that policies and incentives designed to encourage tractable farm-level solutions (Mortensen et al. 2012) are not informed by the best science when the nature of the problem and its causes and effects are not represented or are misrepresented. To state there is a consensus among weed scientists that HR is without a known cause or lacks clear solutions is not supported by the growing body of science in ours and in related pest management disciplines.

\section{Literature Cited}

Barrett M, Soteres J, Shaw D (2016) Carrots and sticks: incentives and regulations for herbicide resistance management and changing behavior. Weed Sci 64(Spec Issue 1):627-640

Coble HD, Schroeder J (2016) Call to action on herbicide resistance management. Weed Sci 64(Spec Issue 1):661-666

Davis AS, Hall C, Jasieniuk M, Locke MA, Luschei EC, Mortensen DA, Reichers DE, Smith RG, Sterling RM, Westwood JH (2009) Weed Science research and funding: a call to action. Weed Sci 57:442-448

Davis AS, Hill JD, Chase CA, Johanns AM, Liebman M (2012) Increasing cropping system diversity balances productivity, profitability and environmental health. PLoS ONE 7:e47149

Duke SO (2012) Why have no new herbicide modes of action appeared in recent years? Pest Manag Sci 68:505-512

Ervin DE, Jussaume R (2014) Integrating social science into managing herbicide-resistant weeds and associated environmental impacts. Weed Sci 62:403-414

Harker KN, O’Donovan JT, Blackshaw RE, Beckie HJ, MallorySmith C, Maxwell BD (2012) Our view. Weed Sci 60: $143-144$ 
Harker KN, O’Donovan JT, Turkington TK, Blackshaw RE, Lupwayi NZ, Smith EG, Johnson EN, Pageau D, Shirtliffe SJ, Gulden RH, Rowsell J, Hall LM, Willenborg CJ (2016) Diverse rotations and optimal cultural practices control wild oat (Avena fatua). Weed Sci 64:170-180

Jussaume RA, Ervin D (2016) Understanding weed resistance as a wicked problem to improve weed management decisions. Weed Sci 64(Spec Issue 1): 559-569

MacDonald JM, Penni K, Hoppe RA (2013) Farm Size and the Organization of U.S. Crop Farming. Washington, DC: U.S. Department of Agriculture Economic Research Report 152. Pp 25-28

Maxwell BD, O’Donovan JT (2007) Understanding weed-crop interactions to manage weed problems. Pages 17-33 in Upadhyaya MK \& Blackshaw RE, eds., Non-chemical Weed Management: Principles, Concepts and Technology. Oxfordshire, UK: CAB International
Mortensen DA, Egan JF, Maxwell BD, Ryan MR, Smith RG (2012) Navigating a critical juncture for sustainable weed management. BioScience 61:75-84

Shaw DR (2016) The "wicked" nature of the herbicide resistance problem. Weed Sci 64(Spec Issue 1): 552-558

Walsh M, Newman P, Powles S (2013) Targeting weed seeds incrop: a new paradigm for global agriculture. Weed Technol 27:431-436

Zimdahl RL (1991) Weed Science: A Plea for Thought. Washington, DC: U.S. Department of Agriculture, Cooperative State Research Service. 34 p

Received November 18, 2016, and approved November 21, 2016.

Associate Editor for this paper: William Vencill, University of Georgia 